\title{
Evaluate the Barriers to Attract Sponsors in the Sport: Industry of Khorasan Razavi
}

\author{
Fatemeh Gharaei ${ }^{1}$, Mehdi Taleb Pour ${ }^{2} \&$ Seyed Morteza Azimzadeh ${ }^{2}$ \\ ${ }^{1}$ Master of sport management physical education and sport sciences group of Ferdowsi University of Mashhad, \\ Mashhad, Iran \\ ${ }^{2}$ Associate professor of faculty of physical education and sport sciences of Ferdowsi University of Mashhad, \\ Mashhad, Iran \\ Correspondence: Mehdi Taleb Pour, Associate professor of faculty of physical education and sport sciences of \\ Ferdowsi University of Mashhad, Mashhad, Iran. E-mail: fatemeh_gharaei@yahoo.com
}

Received: July 20, 2017

doi:10.5539/mas.v11n9p69
Accepted: July 29, 2017

Online Published: August 21, 2017

URL: https://doi.org/10.5539/mas.v11n9p69

\begin{abstract}
Purpose: Evaluate the barriers to attract financial supporters in the sport industry of Khorasan Razavi has been done.

Methodology: The method of this research is applied and descriptive-comparative type. The statistical population of this research includes all managers of factories and private companies, managers of sport clubs and sport authorities of Khorasan Razavi province which among these the 100 CEOs of factories, 114 club managers and sport chairmanparty have been chosen randomly in Mashhad, Sabzevar, Taybad and Kashmar. Questionnaires of sport financial supporters of Ameri and et al (2009) had been the tools under usedwhich the Cronbach's alpha has been obtained as 0.711 in this study. SPSS19 software has been used in order to evaluate data analysis. Research hypotheses has been evaluated by using independent t-test.

Findings: findings showed that the both first and forth hypotheses were confirmed among 4 hypotheses that were tested means that, there is a difference between perspective of managers of private companies and sports managers in relation with barriers of financial supporters and problems related to teams.

Conclusion: Obtained results have been explained and compared based on findings of pervious researches. In fact most managers of companies compared with club managers the lack of sponsor from the sports industry have mentioned as a most important factor and problems related to teams including unpopularity of teams and Lack of using players and famous coaches is important factor for lack of attracting financial supporter in Mashhad from perspective of both groups.
\end{abstract}

Keywords: sport industry, sport sponsors, Khorasan Razavi

\section{Introduction}

In today's world sports have become to a thriving industry from entertainment mere, and has been dedicated itself the large volume of Economic investments; hence Sports clubs also have become to a valid economic firms, and have been found the quite different role from the previous (Azadan, 2012).

Sport sponsor subject because of great impact that has had on the sports industry economic development has always been considered of researchers. In this regard, Gikoo (2004) points to the country's economic conditions as important factors in attracting sponsors for sports notes and know the competitive structure in country's economy as a driving factor for the sponsor development from sport (Gikoo, 2004).

On the other hand, the Huda (2001) and Phan's (2001) findings suggests that the main benefit expectation of investment is the most important factor in attracting sponsor in sports (Huda, 2001 and Phan, 2002). Government and state finances sources are responsible for most financial support from country's sport which due to the government's capital reduction for Investment in sports, sometimes is not Responsive of country's sport needs (Segium et al., 2005).

Asgarian (2004) in his doctoral thesis entitled "Investigation of the Iran's sports industry's economic situation in the 1998 and 2001 years has been earned based on GFSP" estimation, country's sports industry for mentioned years.

Seyyed Ameri (2009) expressed after examining the barriers to attracting sponsors in the sports industry in East 
Azerbaijan, in factors of The lack of utilization from tax exemptions advantages due to sport advertising; lack of suitable advertising venues and facilities at sporting events location; lack of business and financial standards; poor transmission of company commercial messages; time consuming; sponsors' uncertainty in investment in the sports industry due to the uncertainty of the investment future and lack of sports expert managers utilization, there is a significant difference between private companies managers and Sport Managers' opinion in related to the sports sponsor barriers.

Also, Ehsani et al. (2008) during investigating the reasons of lacking sponsors' support from women's sport in Isfahan city expressed that Companies because of the uncertainty from investment in women's section, lack of access to their goals and weak transfer of company's business messages are not willing to invest in this industry.

Elahi et al. (2007) also in studding the barriers to the development attracting revenue from sponsor in football industry the investment uncertainty in the country's football industry due to the lack of this industry development in Iran expressed as an existing barriers in country's sports industry.

Elahi et al. (2009) showed that the most important existing barriers in the Income generation development revenue from the financial support has not been only in the football industry management structure and environmental barriers have an important role in lack of Income generation development resulting from the financial support. The most important defined barriers have a root in the country's economic structure, some legal problems, clubs state-owned, football industry structure and human resources, marketing management, planning football champions, football industry Amenities and facilities.

Bonar et al. (2012) in his research entitled "Investigation of sport sponsor goals in Iran's Premier Leagues" concluded that reputation and Prestige Improvement for company is one of the most important goals and creating advertising challenges and campaign in Medias is the least important purpose. Ramezaninejad et al (2012) in their study showed that awareness of the company and its products, company's brand and logo, a sense of social commitment and media purposes, in order of priority are sports sponsors' important goals.

Rajabi et al. (2012) in his research entitled "Study of firms managers' opinion on the financial support aims from Championship sport" showed that the private companies managers, do not know goals and benefits of sport sponsor from sport championship, achievable.

According to the obtained results from the Jamaat and Ehsani's research (2010) there is significant difference between Sports Federation heads and Supporter companies' managers about sponsor goals groups from sport.

Dayer, Mellor, Mistilis and Moles (2000) introduce the most important role of events of sports as tourist attraction and Media coverage but in addition can be pointed to players' transfers, the coach exporting, ticket sales and advertising, creating facilities and athletic Installation, battings and sponsors' attraction which is such as other sporting events achievements as most original product of this industry (Azadi,2015; Estatler, 2013).

Abrahamson (2003), Eivarson (2004), Segvin (2005), estralayz (2005), and Faed (2007) know the role of media coverage and global advertising very important in attracting sponsors and declare that whatever sports competitions TV and satellite shows be broader at the national and inter-national level, sponsors attraction rate will be more.

Huda (2001) in his study concluded that primary expectation benefit of investment, is the most important factor of financial investment attraction in sports and if the sponsors become sure that will benefit more than other options then Invest in sport. (SOFI, 2013; Jamshidi, 2015).

Radischy (2014) also showed that sports sponsors are emulating the huge variety of contracts - currency transactions, strategic alliances, consortia, etc. that includes assets that complement each other - technology, distribution channels, and financial resources and functions - R \& D, marketing, organization.

In addition, by implementing company's sports participation or institutional sponsors are able to emerge among the various stakeholders and achieve International exposure. The researches results show that, various organizations that are responsible for the country's sport will not be able to provide their needs relying on the government budget.

Now the financial support issue in most of the clubs and sports teams in our country changed to one of the sport managers' major and main concerns. For this reason, understanding this pint that what factors do exist as obstacle in the way of investment companies and private factories in the sports industry and, how can remove and overcome these barriers?

Have prompted researcher to by identifying existing barriers in private companies and by comparing existing barriers companies managers' perspectives in private companies' Investment and by comparing perspectives of private companies managers and sports managers to provide suitable solutions for removing barriers to investment management firms, private companies, and to compare perspectives managers of private companies, 
appropriate solutions to remove barriers and increase investment sponsors in the sports industry, to...sport managers, Federations, teams and different sport fields athletes of states and country from this research results and to offer effective strategies in sponsors attraction to sport managers.

\section{Research Aims}

Aims of this research are summarized in two parts of general purpose and special purposes. The general purpose: investigating the sponsors' attraction barriers in sports industry of Khorasan Razavi Province.

\section{Special Aims}

- Comparison between perspectives of private companies managers and sports managers related to sports supporters' barriers and community's problems

- Comparison betweenperspectives of private companies managers and sports managers' related to sports supporters' barriers and company's internal problems

- Comparison between perspectives of private companies managers and sports managers' related to sports supporters' barriers and problems related to management

- Comparison between perspectives of private companies managers and sports managers' related to sports supporters' barriers and team's problems

\section{Method}

The present is type of applied methods. The Intended research methodology is the descriptive-comparing.

\subsection{Statistical Population}

Present research includes all factories' managers and private companies, sports clubs managers and sports bureau authorities of Khorasan Razavi province.

The aim of factories and companies managers is Managing Manager and marketing manager of the company or factory and the order of team or Board managers is team manager or Supervisor and Board Secretary or Chairman that their numbers are equal to 1068 people.

Sample volume: of these, sample volume has been chosen as 278 people based on Morgan's table and questionnaire has been distributed and only 100 questionnaire of them have been returned to researcher that were related to factories and private companies' managing manager and numbers of 316 teams and sport boards that sample volume has been chosen based on Morgan table 175 people that 114 questionnaire of them have been returned to researcher which were related to 114 team's managers and Chairman of Sports Board in Mashhad and three county of Taibad, Sabzevar and Kashmar have been chosen as a statistical sample randomly.

\subsection{Data Collection Tools}

\subsubsection{The Data Collection Tools}

Intended information in this research proportional to research chapters can be as library and field research. Questionnaire of sport financial supporters has been used in order to collecting field data. This questionnaire has been designed in order toevaluating barriers to attract financial supporters in the sport industry by Ameri and et al in 2009. Formal validity of that was confirmed bysome expert professors of management and sports management and preliminary study has been done for questionnaire reliability test and reliability coefficient of the questionnaire has been obtained as 0.813 by using Cronbach's Alpha coefficient, which it shows the high validity of the questionnaire (Ameri and et al 2009). Cronbach's Alpha has been calculated in order to more evaluating of reliability of this research and it has been obtained as 0.711. Data analysis:In this research, descriptive and inferential statistics has been used order to evaluate the collected data analysis by using spss software. In descriptive statistics section data has been analyzed data by using tables and graphs and frequency distribution charts. Research hypotheses have been evaluated by using independent t-test in inferential statistics section.

\subsection{Research Findings}

This research has been done on 114 persons of Managers and Chairman of the Board of clubs and 100 people of the CEOs of factories of Mashhad and Taybad, Sabzevar and Kashmar cities. According to obtained results from Descriptive tables, the maximum frequency has been related to diploma educations among the managers and chairman's of the board director and bachelor among the factories CEOs. Also most of the participants' clubs had been private.

Just 1.8 percent of them had been governmental and 1.8 percent of them had been dependent to government and 92 percent of Participating clubs had been private in this research. Most of participating factories in this research had been private. Among the participating factories, 1 percent of them had been governmental, 21 percent of 
them had beensemiprivate and 77 percent of them had been private and participating factories in this research had been industrial, electronically,alimentary and clothing which among this the industrial factories had the most frequency. Also the supported sports teams by factories more include football and volleyball and whereas from perspective of sports club managers such as epic, chess and gymnastics need more sponsor from other sports.

Independent t-test was used order to testinghypotheses and Shapiro-Wilk test was used order to evaluating normality of data. The result of the test showed that, research variables have normal distribution.

\subsection{The First Hypothesis}

There is a difference between perspective of private companies' managers and sports managers related to barriers of sports sponsors and community problems.

Table 1. Result of the $\mathrm{T}$ test in first hypothesis

\begin{tabular}{lccc}
\hline Variable & $\mathrm{T}$ & $\begin{array}{l}\text { Freedom } \\
\text { degree }\end{array}$ & $\begin{array}{l}\text { Significant } \\
\text { level }\end{array}$ \\
\hline Community & -6.321 & 212 & 0.001
\end{tabular}

Table 2. Result of the $\mathrm{T}$ test in second hypothesis

problems

\begin{tabular}{lccc}
\hline Variable & $\mathrm{T}$ & $\begin{array}{l}\text { Freedom } \\
\text { degree }\end{array}$ & $\begin{array}{l}\text { Significant } \\
\text { level }\end{array}$ \\
\hline Companies & -1.74 & 212 & 0.08
\end{tabular}

Independentt-test was used in order to testing this hypothesis. The result of this test has been shown in table 1 . According to significant level that is less than 0.05 the null hypotheses is rejected means that, there is a difference between perspective of managers of private companies and sports managers in relation with barriers of sponsors and community problems.

The second hypothesis: There is a difference between perspective of private companies' managers and sports'managers related to Barriers of sports sponsors and inner problems of the companies.

Independent t-test was used in order to testing this hypothesis. The result of this test has been shown in table 2 . According to significant level that is more than 0.05 the null hypotheses is accepted means that, there is not any difference between perspective of managers of private companies and sports managers in relation with barriers of sponsors and inner problems of the companies.

The third hypothesis: There is a difference between perspective of private companies' managers and sports'managers related to Barriers of sports sponsors and problems related to management.

Table 3. Result of the $\mathrm{T}$ test in third hypothesis

\begin{tabular}{llll}
\hline Variable & $\mathrm{T}$ & $\begin{array}{l}\text { Freedom } \\
\text { degree }\end{array}$ & $\begin{array}{l}\text { Significant } \\
\text { level }\end{array}$ \\
\hline $\begin{array}{l}\text { Management } \\
\text { problems }\end{array}$ & 0.121 & 212 & 0.5 \\
\hline
\end{tabular}

Table 4. Result of the $\mathrm{T}$ test in forth hypothesis

\begin{tabular}{llll}
\hline Variable & $\mathrm{T}$ & Freedom degree & Significant level \\
\hline Team problems & -2.773 & 212 & 0.006 \\
\hline
\end{tabular}

Independent t-test was used in order totesting this hypothesis. The result of this test has been shown in table 3 . According to significant level that is more than 0.05 the null hypotheses is accepted means that, there is not any difference between perspective of managers of private companies and sports managers in relation with barriers of sponsors and problems related to management.

The forth hypothesis: There is a difference between perspective of private companies' managers and sports'managers related to Barriers of sports sponsors and problems related to teams.

Independent t-test was used in order to testing this hypothesis. The result of this test has been shown in table 4 . According to significant level that is less than 0.05 the null hypotheses is rejected means that, there is difference between perspective of managers of private companies and sports managers in relation with barriers of sponsors and problems related to teams.

\section{Discussion and Conclusion}

This research has identified the existing barriers for investment in private companies in sport industry and comparing the perspectives of the private company managers and sports managers in this regard, in direction of the research purposes the following results was obtained;

The result of the first hypothesis showed, there is a significant relationship between perspective of the private company managers and sports managers related to barrios of the sports financial supporters and community problems. According to the questions of the questionnaire about problems related to community (lack of supporting the press and newspapers, lack of media coverage, lack of utilization from benefits of tax breaks) in fact most of the companies' managers has mentioned these factors as a lack of sponsor from sport industrial compared with clubs managers. In this direction, Abrahamson (2003), Ivarsson (2004), Seguin (2005), Strelize (2005) and Faed (2007) and Ameri know the role of the media coverage and advertising nationwide very 
important in attracting financial supporters and they express whatever the satellite and TV shows of sports competition be more extensive at national and international levels the amount of attracting the financial supporters will be more.

Since the all sports habits and behaviors of the community persons, attitudes and beliefs of them in sports problems has been mutual affected by community and media bents, one of the support ways from these attitudes and beliefs in right way is considering toinserted contents in the sports press and media of TV and radio since in fact TV and radio is monitor of the sports level and status in country and in international level. So, not only TV and radio have role in attracting the people of the community but also is effective in attracting sports sponsors.

On the other hand, when financial supporters don't see lack of the right and widespread supporting from media they see the investment in this section costly and they find the probability of returning investment very less and its reason is that the investors not only know themselves responsible in sponsor section from a team but also they know themselves responsible inadvertising and media sectors to become successful in the event that this task is mostly responsible for public media.

The result of the second hypothesis test showed there is no significant relationship between perspective of the private companies' managers and sports managers related to barriers of the sports financial supporters and inner problems of the companies. According to the questions of the questionnaire about inner problems of companies (effective evaluating problem, lack of confidence of financial supporters from investment in sports industry due to uncertainty of future the investment, time-consuming) in fact most of the companies' managers and gyms' managers of both groups, have mentioned these factors as a lack of sponsor from sports industry.

In this direction Huda (2001) has mentioned the expectation of the benefit origin resulted from investment as a most important factor of attracting investment of financial supporters in sports and expresses that financial supporters will invest in sports section if they assured that they will achieve more benefit from other options also Ehsani and colleagues (2008) in evaluating reasons of the lack of supporting of the financial supporters from women sports in Isfahan mentioned that companies are not willing to investment in this industry due to lack of confident from investment in women sports section.

The result of the third hypothesis test showed there is no significant relationship between perspective of the private companies' managers and sports managers related to barriers of the sports financial supporters and problems related to management. According to the questions of the questionnaire about these problems (Lack of sports marketing experts, lack of national and work standards, lack of exploiting the benefits of tax exemption, lack of places and advertising proper facilities, transmission of commercial messages of companies)the researches have been done aligned with this study.

For example Doherty \& Murray (2007) have confirmed the non-effective marketing management as the factors of developing the attraction of the sponsorship. Also these results are compatible with findings of the Elahi and et al. (2007) he has considered the unsuitable management and lack of using from commercial thoughts and expertise managers and making money in football industry, unsuitable conditions of the stadiums venue of the competitions to achieve the goals of advertising of sponsor companies and also the lack of transparency in financial information as a exist barriers for attracting investment of financial supporters in sport industry of the country.

And at lastthe result of the forth hypothesis showed, there is a significant relationship between perspective of the private company managers and sports managers related to barrios of the sports financial supporters and problems related to teams. Problems related to teams includeunpopularity of teams and lack of using famous players and coaches. In this direction the research of the Seguin and et al. (2005) mentioned that using popular athletes in sport teams and also extensive media coverage and suitable advertisements are the reasons of the investment of private companies (Maharati \& Colleagues, 2013).

According to findings of this research, gyms' managers know respectively the problems related to teams, problems related to sports management, problems related to community and inner problems of companies as the barriers to attract sports sponsors; However companies' managers the factors of lack of sponsor have expressed respectively as problem related to teams, problems related to community, problems related to sports management and inner problems of the companies. According to these findings, can be realized that problems related to teams that include unpopularity of teams and lack of using famous players and coaches from perspective of both of them is important factor in lack of attracting financial supporting in Mashhad city.

\section{References}

Azadegan, M., Asgarian, F., \& Ramezani, N. R. (2011). Explore ways of attracting sponsors in professional football. Sports Management Studies, 13.

Azadi, R., Yousefi, B., \& Abedi, H. (2014). Sponsor role in enhancing brand equity in sports clothing and sports 
equipment. Communications, media and sports management in the second year.

Bonari, N., Ramezani, N., Rahim, K. M., K-nejad, A., \& Malekakhlagh, E. (2012). Study objectives of sport sponsorship in the major leagues. Sport Management, 14, 161-176.

Elahi, A. R., Sajadi, N., Mohammad, K., \& Abrishami, H. (2009). Barriers to attracting income from sponsor in the Islamic Republic of Iran football industry. Sports Management, 1, 189-202.

Elahi, A. R., Sajjadi, N. Nasrallah, K., \& Mohammed, A. H. (2007). Absorbing barriers to the development of the revenue from sponsorship in the football industry of Iran, the sixth International Conference on Physical Education and Sport Sciences. Kysh9-11.

Fan, Y. (2002). Event sponsorship in China. Corporate Communications: An International Journal, 7(2), 110-116.

Fayed, A. R. (2007). Strategic evaluation of sport sponsorship as a marketing communication tool in Iran electronic industry. Master's thesis under joint marketing and e-commerce, Luleå University of Technology Madras.

GiKoo, Y. (2004). Sport sponsorship match-up effect on consumer based brand equity: An application of the schematic information process, Unpublished doctoral degree dissertation. Department of sports management, recreation management and physical education. Florida State University.

Huda, H. Al-Khaja (2001). Investors perspectives about sports marketing in Bahrain. The sport Journal, 4(4).

Ivarsson, C., \& Johnson, M. (2004). Sport Sponsorship as a promotional tool, Bachelors Thesis, Industrial Marketing and e-Commerce. Lulea University of Technology.

Jamaat, K., \& Mohammad, E. (2011). Goals direct and indirect sponsor of sports in the country. Research in sports science. Number, 10, 57-72.

Jamshidi, O., Hamidi, M., \& Mohammad, K. (2015). Sportswear industry's competitive situation analysis using Porter's competitive model. Applied Research in Sport Management, 1, 105-115

Maharati, Y. B., \& Elham, L. (2013). Hadiyeh. Ethics in scientific research process. Journal of Ethics in Science and Technology, 9(1).

Mohammad, E., \& Sharifian, E. T. (2013). Management support programs in athletics. National Academy of Olympic and Paralympic Islamic Republic of Iran. Presented by Pvrpvyt.

Radicchi, E. (2014). Sports Sponsorship Evolution in the Economic Recession: Analytical Evidence from Empirical Cases. Physical Culture and Sport. Studies and Research. https://doi.org/10.2478/pcssr-2014-0005

Rajabi, M., Soltan, H., Mohammad, H., Razavi, M., Hosseini, E., \& Kharkan, K. (2012). Viewpoints corporations on the objectives of sport sponsorship championship. Journal of Sport Management, 4(12), 23-36.

Ramezaninejad, R., Bonari, N., Khabiri, M., K-nejad, A., \& Malekakhlagh, E. (2012). Factors affecting the decision-making sport sponsorship. Sport Management, (12), 126-107.

Seguin, B., Teed, K., \& O'Reilly, N. (2005). National sports organizations and sponsorship: An identification of best practices. International Journal of Sport Management and Marketing, 1(1/2), 69-92.

Seyyed, A., Mir, H., Moharramzadeh, M., Bashiri, M., \& Hadi, H. (2009). Sponsor for the study of sports marketing mix elements. Quarterly Olympic, 18(4), 52.

Strelize, B. (2005). Relationship in sport sponsorship: A marketing perspective. Unpublished doctoral degree dissertation, faculty of management, University of Johannesburg.

Stutler, D. K. (2013). Sports sponsors. Translators. Mehdi Talebpour, Vahid Saatchian, Mohsen Esmaeili. Tehran. Institute of Physical Education and Sport Sciences.

Sufi, M., \& Shabani, A. (2013). The effect of mass media on the financing of sport. Communication Management in Sports Media, 1(2).

\section{Copyrights}

Copyright for this article is retained by the author(s), with first publication rights granted to the journal.

This is an open-access article distributed under the terms and conditions of the Creative Commons Attribution license (http://creativecommons.org/licenses/by/4.0/). 